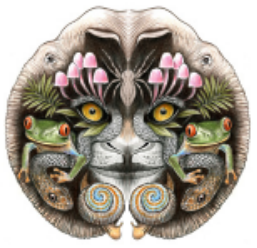

ISSN 0974-7907 (Online) ISSN 0974-7893 (Print)

OPEN ACCESS

\title{
EFFECTIVNESS Of THE GNRH ANALOGUE DESLORELIN AS A REVERSIBLE CONTRACEPTIVE IN A NEOTROPICAL PRIMATE, THE COMMON MaRmoset Callithrix Jacchus (MAMmalia: Primates:

1,2,3,4 University of Sao Paulo, School of Veterinary Medicine and Animal Science, Department of Animal Reproduction (VRA), Brazil

${ }^{1}$ dro@usp.br (corresponding author), ${ }^{2}$ priviau@usp.br, ${ }^{3}$ cadolive@usp.br, ${ }^{4}$ cspizzutto@yahoo.com.br

\begin{abstract}
Deslorelin is a synthetic GnRH analogue, which is being used as a contraceptive in animals by acting as a gonadal suppressant. The product Suprelorin (Virbac, Australia) contains deslorelin as a biocompatible, slow release subcutaneous implant. The continuous release of deslorelin provokes a down-regulation of $\mathrm{GnRH}$ receptors, and subsequently, inhibition of the synthesis and release of the gonadotropins FSH and LH, necessary for gonadal activities. The intention of this study was to investigate the effectiveness of a subcutaneous deslorelin acetate implant $(2,35 \mathrm{mg})$ in suppressing ovarian cyclic activity and inhibiting ovulation in captive Common Marmoset Callithrix jacchus, and investigate the reversibility of the treatment. Two experimental groups were formed, group deslorelin (D) with three couples and control group (C) with two couples. To monitor the effect of the implants, hormones indicating ovarian cyclic activity were monitored non-invasively by enzyme immunoassay (fecal monoclonal antibody anti-progesterone CL 425). Fecal samples were collected three times a week from all females during three trial phases (phase I: month 1,2,3 and 4; phase II: month: 5,6 and 7 and phase III: month 8,9 and 10). In contrast to expectations the results of this trial indicated that there was no suppression of the ovarian cyclic activity, nor inhibition of the ovulation after the application of the implants. The outcome of our trial can possibly be explained by the fact that the dosage of $2.35 \mathrm{mg}$ of deslorelin is not effective in $C$. jacchus. We confirmed significant changes $(p<0.05)$ of P4 metabolites from phase I to phase II due to the treatment after the implantation of the GnRH analogue Deslorelin. The employed non-invasive fecal progesterone monitoring could be biologically validated and proved to be efficient in the detection of ovarian cyclic activity in this neotropical primate species, $C$. jacchus.
\end{abstract}

Keywords: Callitrix jacchus, deslorelin, GnRH analogue, non-invasive analysis, reversible contraception.

DOI: http://dx.doi.org/10.11609/jott.2305.8.4.8652-8658

Editor: Ulrike Streicher, University of Oregon, Eugene, USA.

Date of publication: 26 April 2016 (online \& print)

Manuscript details: Ms \# 2305 | Received 20 September 2015 | Final received 13 April 2016 | Finally accepted 14 April 2016

Citation: Rosenfield, D.A., P. Viau, C.A. Oliveira \& C.S. Pizzutto (2016). Effectivness of the GnRH analogue deslorelin as a reversible contraceptive in a neotropical primate, the Common Marmoset Callithrix Jacchus (Mammalia: Primates: Callitrichidae). Journal of Threatened Taxa 8(4): 8652-8658; http://dx.doi.org/10.11609/ jott.2305.8.4.8652-8658

Copyright: (c) Rosenfield et al. 2016. Creative Commons Attribution 4.0 International License. JoTT allows unrestricted use of this article in any medium, reproduction and distribution by providing adequate credit to the authors and the source of publication.

Funding: FAPESP (Fundação de Amparo à Pesquisa do Estado de São Paulo) 2012/13217-5.

Conflict of Interest: The authors declare no competing interests.

For Portuguese abstract see end of this article.

Author Details: Derek Andrew Rosenfield (DRO) works as a veterinarian and post-graduate in wildlife research at the Department of Animal Reproduction, Faculty of Veterinary Medicine and Animal Science at the University of Sao Paulo, with focus on Wildlife population control, employing non-lethal and reversible contraceptive methods; Cristiane Schilbach Pizzutto (CSP), veterinarian, and post doctorate from the Faculty of Veterinary Medicine and Animal Science, University of São Paulo, currently working with animal welfare and environmental enrichment; she is regional coordinator of The Shape of Enrichment (Shape Brazil). Priscila Viau (PV) is veterinary and technician of the hormonal dosage laboratory (HDL) at veterinary medicine school from University of São Paulo; Claudio Alvarenga de Oliveira (CAO) is veterinary, professor and coordinator from hormonal dosage laboratory at Department of Animal Reproduction - Faculty of Veterinary Medicine and Animal Science, University of São Paulo; Marcelo Alcindo de Barros Vaz Guimarães (MABVG), veterinarian and professor of wildlife reproduction, at Department of Animal Reproduction - Faculty of Veterinary Medicine and Animal Science, University of São Paulo.

Author Contribution: DRO and MABVG designed the project; DRO was responsible for the collection of samples and preparation for hormone dosage; PV and CAO helped at the hormonal dosage; DRO, CSP and MABVG were responsible for data analysis, DRO wrote the article, CSP and MABVG were responsible for review of the article and for the supervision of the project.

Acknowledgements: We would like to thank the team of the Municipal Zoo, Guarulhos for the cooperation and providing access to the animals, Peptech Australia (now Virbac, Aus.) for providing the Deslorelin implants, and FAPESP for the financial support.
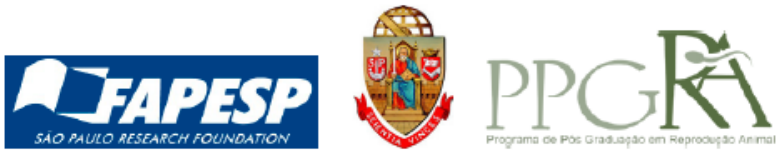


\section{INTRODUCTION}

To control wild animal populations in captivity is an important management aspect, as in most cases space and resources are limited and some species have a high reproductive rate. But it is important to do so in the most responsible manner (for instance, trying to avoid sacrificing animals). This has particular significance when managing endangered species striving to maintain their genetic diversity. In situ population control can be of even greater importance, for example to minimize potential human-wildlife conflicts, while trying to maintain an ecological balance or when an invasive species competes for limited habitat and food resources with native species. The total removal of such invasive species does represent an impossible task, and methods as culling might be against local laws, or are publically not accepted, even if the species in question is considered invasive. In situations like this, applying contraceptive methods for population control, might represent the best option. For population control of endangered species in situ, these contraceptive methods must be reversible, causing temporary infertility, without the risk of losing the animal's genetic material.

Common Marmosets Callithrix jacchus are considered invasive in the Atlantic Forest region of Sao Paulo in Brazil, based on invasive species characteristics as described by Richardson (2000). As a result of their adaptability and high reproduction rate, they compete for living space with native species, such as the Buffy-tufted Marmosets Callithrix aurita. C. aurita are increasingly endangered through overcrowding, competition for food and territorial rivalry in addition to the ongoing habitat loss due to urbanization within their distribution area (Thiago 2008).

In captivity populations of Common Marmosets reproduce very well, overcrowding existing spaces in zoological and ecological parks and increasing the overall costs of their care (Image 1). Due to their reproductive characteristics $C$. jacchus was considered an excellent biological model for the development of reversible contraceptive methods. Common Marmosets are polyestrous (24 to 30 days/cycle, up to 4 cycles per year), non-seasonal, polyovular (one to three, mostly twins), have birth intervals of six months, and reach sexual maturity between 17 to 20 months of age. Gestation lasts between 140 and 150 days (Bluemel et al. 2015).

The reproductive endocrine system is controlled by the communication from hypothalamus to the pituitary gland and from the pituitary gland to the gonads. The most important hormone is the gonadotrophin-releasing

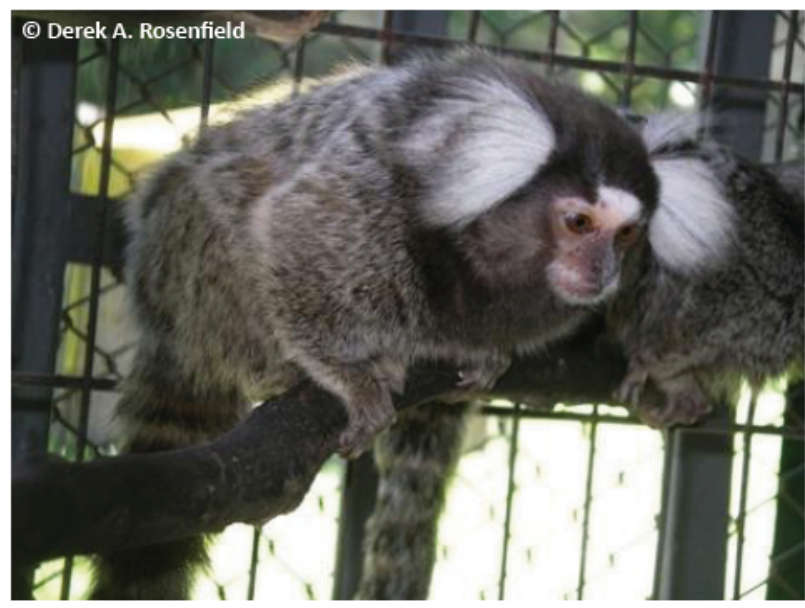

Image 1. Common Marmoset Callithrix jacchus

hormone $(\mathrm{GnRH})$, synthesized in the hypothalamus, which controls the synthesis and release of the luteinizing hormone (LH) and the follicular stimulating hormone (FSH) in the pituitary gland, which in turn are responsible for the synthesis of sex hormones, such as estrogen and testosterone. They are the driving force of the gonadal activity, and the development of secondary sex characteristics and behavior, besides other physiological functions.

A prior study assessing deslorelin acetate as a longterm contraceptive drug in female Tammar wallabies showed promising results by inhibiting follicular development (Herbert 2004). Other studies confirmed antifertility effects in a number of different mammalian species of both sexes, such as male Tammar Wallabies (Herbert 2007), male wild boar (Kauffold 2010), female lions and female tigers (Bertschinger 2008).

At the time of this project, very few studies were available on the use of deslorelin as a contraceptive method in Common Marmosets. One study conducted in 2006, determined basal cortisol concentrations in females, subjected to long-term treatment with leuprolide acetate, a GnRH agonist known to suppress ovarian activity. In this study the used GnRH agonist successfully inhibited ovulation in $100 \%$ of the treated females for a prolonged time (Saltzman et al. 2006).

Synthetic GnRH analogues are similar to the natural GnRH peptides in their structure, except that they are modified at the sites of enzymatic degradation and therefore have an increased half-life (Gobello 2007). As they all are susceptible to degradation by gastrointestinal peptidase, parenteral administration is obligatory (Padula 2005) for example in form of subcutaneous implants.

Deslorelin acetate is a GnRH agonist that can be used 
in the form of biocompatible subcutaneous implants, providing a slow release for months or even years (Munson et al. 2001). Continuous exposure to high concentrations of deslorelin after an initial peak promotes a "down-regulation" of GnRH receptors. This results in inhibition of the synthesis and secretion of both pituitary gonadotropins, LH and FSH and consequently leads to a suspension of the cyclic ovarian activity (D'Occhioa et al. 2000; Ortmann et al. 2002). Once all the deslorelin of the implant has been released, or the implant has been removed, the suppressive effect ceases, and the ovaries return to cyclic activity, characterizing the reversibility of this method (Bertschinger \& Guimarães 2008).

We chose the GnRH analogue deslorelin for this study, due to its usage history, the known effectiveness in other species and because little or no adverse effects on physiology, behavior, social organization of the animals were known. Furthermore its use is economically viable, and its effects are potentially reversible as above studies had shown (Herbert 2004, 2007; Bertschinger 2008; Kauffold 2010).

GnRH agonists are considered a better alternative as contraceptive hormonal method than analogues of the gonadal hormones, such as progestin, as this potent synthetic is often associated with adverse effects, such as growth of the endometrium and the mammary glands (Kutzler \& Wood 2006). Other disadvantages reported from the field are a delay in the return of ovarian activity in some species (felids), loss of secondary sex characteristics in males of some species due to the suppression of testosterone synthesis, and some weight gain (Munson et al. 2002).

To minimize stress and discomfort, which for example collecting blood samples would cause, we employed a non-invasive method to monitor endocrinological changes (Munro \& Stabenfeldt 1984). The present study was designed to investigate whether a slow release of the GnRH-agonist would effectively suppress ovarian cyclic activity in adult females of $C$. jacchus, and to demonstrate the reversibility of the contraceptive effect after implant removal. In addition the study aimed to verify the selected method of non-invasive monitoring of ovarian cyclic activity by measuring fecal progesterone metabolite concentrations. The present study was approved by the Bioethics Commission of the School of Veterinary Medicine and Animal Science, São Paulo University (FMVZ, USP), Brazil under the protocol \# 2991/2013.

\section{MATERIALS AND METHODS}

\section{Animals and location}

For this research project five adult Marmoset females kept at the Municipal Zoo Guarulhos, Sao Paulo, Brazil, served as the study subjects. All females had lived at this zoo for a minimum of $\mathbf{1 8}$ months prior to this study.

All females were paired with their respective male partners and were kept in outdoor cages $(100 \mathrm{~cm} x$ $50 \mathrm{~cm} \times 50 \mathrm{~cm})$, which included a night box. Males and females were separated by a metal-mesh screen (Image $2)$, allowing for visual, auditory and olfactory contact, so the couples could remain together, but without the possibility to copulate. All cages were equipped with removable bases allowing for the collection of fecal samples.

The diet offered to the animals each morning and afternoon consisted of $100 \mathrm{~g}$ of a special small primate food (Megazoo ${ }^{\circledR}$, Green Valley, Brazil), 200g of milk powder, $10 \mathrm{~g}$ of acacia gum (gummi arabicum), 1 tablespoon of honey and $550 \mathrm{ml}$ boiled water. Each Marmoset received $15 \mathrm{ml}$ of this mixture per meal. Water was available ad libitum. All females were in sound condition, clinically healthy and had intact reproductive systems.

The Marmosets were randomly divided in two groups. "Group D" comprised three females selected for the deslorelin treatment and "Group C" consisted of two females and acted as the control group.

\section{Duration}

The entire study period was divided in three phases:

Phase One - This phase aimed to confirm the cyclic ovarian activity of all females by monitoring progesterone metabolite levels. It lasted four months

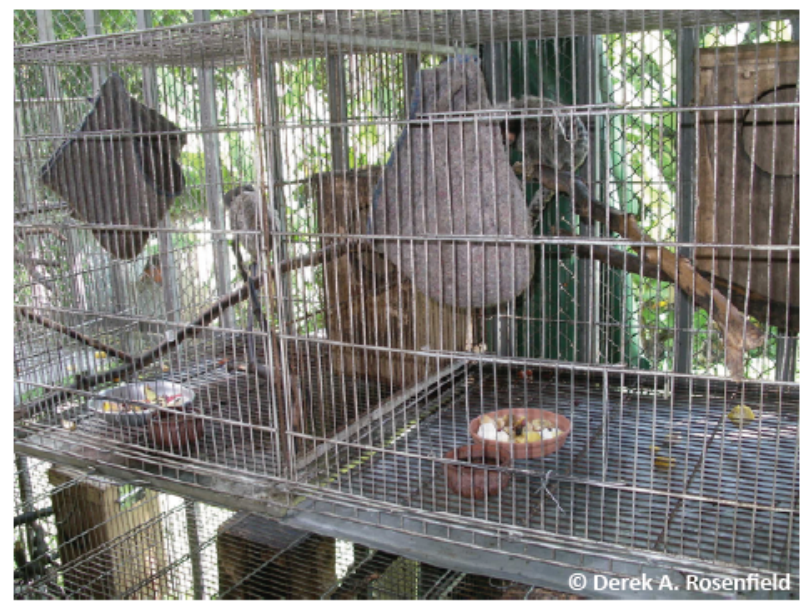

Image 2. Metal-mesh cage system 
and covered potentially three ovarian cycles.

Phase Two - Placement of implants. During this phase we monitored the ovarian activity under the influence of deslorelin. This phase lasted three months.

Phase Three - Implant removal. Fecal hormone level after withdrawal of deslorelin. The duration of this phase was also three months.

\section{Sample collection}

Fecal samples were collected three times a week, always in the morning between 08:00 hr and 10:00 hr. The samples were stored in plastic zip lock bags, labeled with date, time of collection, animal ID and immediately stored in a freezer at $-29^{\circ} \mathrm{C}$, until shipment to the laboratory for hormonal dosages at the Department of Animal Reproduction, Faculty of Veterinary Medicine and Animal Science, University of São Paulo.

\section{Implant application and removal}

The three females of group D were anesthetized with a combination of Tiletamine and Zolazepam (Zoletil ${ }^{\circledR}$ Virbac Brazil) at a dose of $5.5 \mathrm{mg} / \mathrm{kg}$ intramuscularly (Flaiban et al. 2009). Once tranquilized, all three females received a subcutaneous implant, containing $2.35 \mathrm{mg}$ of deslorelin acetate (Suprelorin ${ }^{\circledR}$ Peptech Animal Health, Australia). The two females of group $\mathrm{C}$ also were anesthetized, but did not receive any implants. After the recuperation all females were returned to their cages.

To remove the implant all females were anesthetized following the anesthetic protocol described above and the implants were surgically removed from the three females of group D. After the recuperation all females were returned to their cages.

\section{Hormone metabolite analysis}

All samples were kept frozen at $-20^{\circ} \mathrm{C}$ until the extraction process. To start the extraction, samples were thawed and transferred to Eppendorf plastic tubes, prior marked with the animal and sample identification numbers. They were placed in a vacuum freeze-dryer system where they were lyophilized at a temperature of $-51^{\circ} \mathrm{C}$ for 24 hours, thereby removing all moisture, preventing further deterioration of the fecal progesterone metabolites.

The samples then were manually homogenized within the same plastic tubes and weighed on a precision scale (Mettler, United States). Quantities of 0.1g mass dry weight, or as close as possible to this value but at least 0.05 gram were collected and filled into Ensaio test tubes, marked, sealed with Para-film (Pechiney Plastic Packaging Company, United States ) and stored under refrigeration until further preparation. Samples with less than $0.05 \mathrm{~g}$ were not included in the analysis.

The extraction of the progesterone metabolites was performed according to the method described by Palme (2005), starting with the homogenization of $0.05 \mathrm{~g}$ to $0.1 \mathrm{~g}$ of fecal dry matter in a solution of $80 \%$ methanol by vortexing them for 15 minutes. In order to guarantee adequate readings and curve interpretation it was important to determine the correct dilution factor. We applied the following procedure: $5 \mathrm{ml}$ of a methanol 99.8\% solvent (PA ACS Synth, SP Labor, Brazil) were diluted to a concentration of $80 \%$ with distilled water. A volume of $5 \mathrm{ml}$ of $80 \%$ methanol was added to each of the tubes, containing the fecal samples. The mixture was homogenized with the multi-vortex device (Multi Tube Vortexer 2500 DVX, VWR, United States) for 15 minutes at $2500 \mathrm{rpm}$ rotation. The tubes were then centrifuged (Universal 320 centrifuge, Hettich, United States) for 15 minutes at $3500 \mathrm{rpm}$. $1 \mathrm{ml}$ volumes of the supernatants were micropipetted and transferred to Eppendorf plastic tubes, marked and stored in a freezer at $-20^{\circ} \mathrm{C}$ until further processing.

The concentrations of the hormone metabolites were measured using an enzyme immunoassay based on the procedures described by Munro et al. (1984). To measure the metabolites, prepared samples were diluted in gelatin buffer pH 7.0 (13.8g NaPO 4, 9.0g NaCl, 1.0g NaN3, 1.0g gelatin, $1000 \mathrm{ml} \mathrm{H2O}$ ). Anti-progesterone monoclonal antibodies CL425 and HRP conjugated progesterone 3-O-carboxymetiloxime were used in the test and the consequent readings were performed in a multimode detector (DTX 800 system, Beckman Coulter, United States). The results of the concentrate obtained were expressed in $\mathrm{ng} /$ well.

\section{RESULTS}

Figure 1 illustrates the results of one exemplary female of group D. All females from group D showed cyclic ovarian activity during the entire phase I. In phase II, after the deslorelin implantation, all group D females showed promptly an initial increase in ovarian activity and concentrations of fecal progesterone metabolites increase above the peak values previously established for all females. The increase in phase II was significantly above the mean of the concentrations of fecal metabolites in all the implanted females in phase I $(P>0.05)$. Progesterone concentrations remained elevated during phase II and ovarian cyclic activity never seized. The suggested suppression of the ovarian activity 


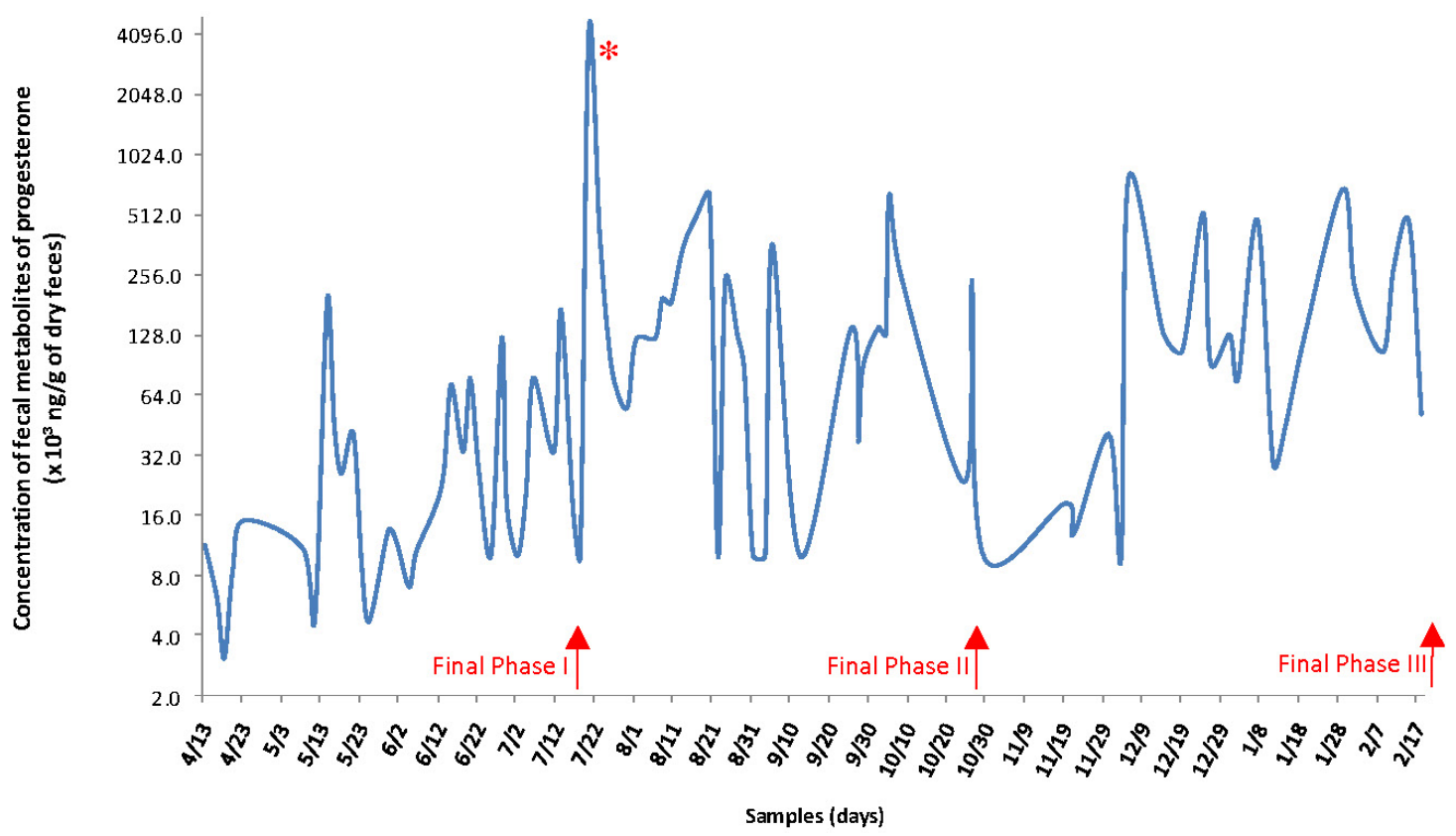

Figure 1. Exemplary female from the Deslorelin Group; Progesterone Metabolite Concentration during: Phase I - pre-implant; Phase II - implant; and Phase III - post-implant; * marking the initial stimulus post-implant.

resulting from a down-regulation of $\mathrm{GnRH}$ receptors could not be observed. After removal of the implants, in phase III, all the females of group D continued to show cyclic ovarian activity.

All females of group $C$ showed ovarian cyclic activity during all three phases of the study. Interestingly the ovarian cyclic activity in this group increasingly coincided over the course of the study.

The study validated the suitability of the immunoassay tests performed. The resulting values for the $\mathrm{P}_{4}$ metabolite parallelism test were $\mathrm{Y}=4.988+0.89$ * $\mathrm{X}$ and $\mathrm{R} 2=0.972$, demonstrating that the antibody used in the assays was adequate in detecting the searched metabolites in the fecal matrix. The inter-assay variations of the hormone tests were between $5.3 \%$ and $9.9 \%$ the intra-assay variation coefficients between $2.5 \%$ and $5.8 \%$, respectively. Using the calibration curve the assay sensitivity was quantified with $2.0 \mathrm{ng} /$ well.

\section{Statistical analysis}

Data analysis included assessing the normal distribution of the residues, and testing for the homogeneity of variance using the SAS/LAB ${ }^{\circledR}$ Guided Data Analysis application. The mean fecal progesterone metabolite (FPM) concentration was determined using all samples of each individual in each group. All samples with values two standard deviations (SD) above the mean were removed. The mean was recalculated, and this process was repeated until all values were within two SD from the mean. The resulting mean value was designated the baseline value, and all values greater than two SD from the mean were considered peak values. This process allows for a statistical assessment of baseline values for biologically relevant hormone concentrations (Heintz et al. 2011). For each phase, the mean FPM concentration and SD were calculated. The means were compared using ANOVA and Tukey's test, both with $\mathrm{P}<0.05$.

The resulting graph from a SAS GLM procedure (Fig. 2) confirms a significant difference of FPM concentration between phase I and phase II; between phase II and phase III no significant difference was observed.

\section{DISCUSSION}

Only few studies on the use of deslorelin implants in neotropical primates can be found in literature and consequently little is known on the dosage necessary to suppress ovarian cyclic activity in these animals. And though a study of Saltzman et al. (2006) reports the effectiveness of a GnRH agonist in inhibiting ovulation in Common Marmoset s, it does not indicate the adequate contraceptive dosage for this species.

Contrary to expectations, the results suggest that the concentration of $2.35 \mathrm{mg}$ deslorelin acetate was not effective to suppress ovarian cyclic activity in Callithrix jacchus, nevertheless the deslorelin implants did 


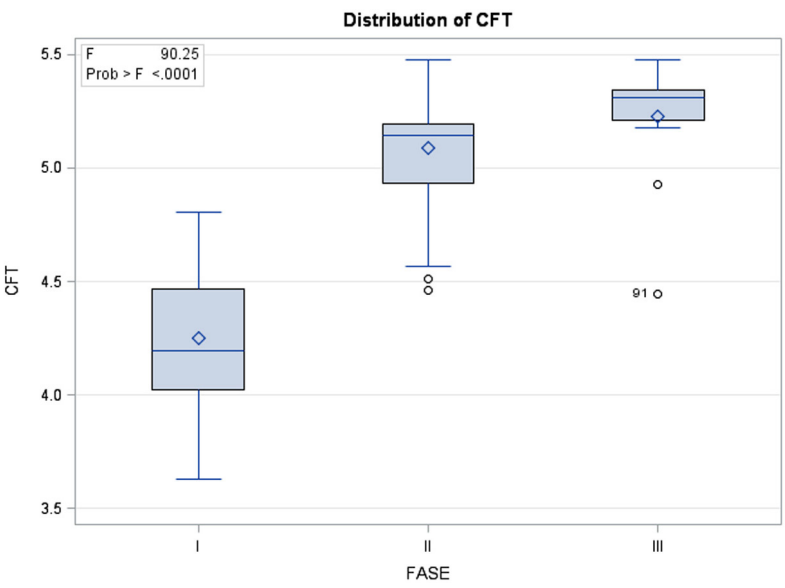

Figure 2. GLM procedure, demonstrating significant difference between phase I and phase II of a deslorelin treated female

cause the expected initial stimulation and increase of ovarian activity in the females and these findings were consistent with the results in other studies and other species (Bertschinger \& Guimarães, 2008). However, during phase II no suppression of the cyclic activity was observed in any of the deslorelin treated females. All females of the control group showed as expected ovarian cyclic activity during all three phases of the study.

At present no effective dosages are published for deslorelin as a contraceptive in New World monkeys, including the information from the two key data bases on contraceptive methods, the "Husbandry Guidelines for Callitrichinae" by the European Association of Zoos and Aquaria (EAZA 2010), and the "Contraception Products and Recommendations" by the St. Louis Zoo Contraception Center (2015).

Nevertheless, numerous studies showed the successful application of deslorelin acetate in a variety of other species, but they were done with a minimum concentration of $4.7 \mathrm{mg}$ of deslorelin acetate. This fact and our own observation of an initial flare of ovarian activity during this study, suggest that deslorelin can still potentially be used as a reversible contraceptive method in Common Marmosets once the right dosage can be found.

The observed synchronization of ovarian cyclic activity in the control group could be explained by the very close proximity of all female Marmosets during this experiment, which allowed for olfactory contact. A mechanism that has been described by McClintock $(1978,1983)$ in rodents.

Pizzutto \& Guimarães (2015) conducted a research on Black-tufted Marmoset (Callithrix penicillata), with focus of the study on concentration of fecal metabolites of glucocorticoids (FGM) after stressful stimuli by enzyme immunoassay method. Furthermore, to determine whether FGM concentrations fluctuate diurnally in $C$. penicillata in captivity. One of the presented findings showed that FGM concentrations in females were consistently higher than in males. Pizzutto hypothesized that the results may reflect: "high dependence of the physiological impact of stressors on the perception of environmental stimuli", such as produced in captivity. A premise that must be considered as an important reproductive parameter, potentially interfering with hormone-based contraceptive treatments.

The non-invasive method to monitor the hormonal levels, the extraction and quantification of fecal progesterone metabolites proved to be efficient in identifying cyclic ovarian activity in the studied species.

\section{CONCLUSION}

The sub-cutaneous application of a $2.35 \mathrm{mg}$ deslorelin acetate implant, was not effective to suppress ovarian cyclic activity or ovulation in $C$. jacchus.

Tests performed to measure the concentrations of fecal progesterone metabolites were biologically validated and proved to be efficient for the detection of ovarian activity.

It becomes apparent that many aspects of the reproductive physiology and the dynamics of contraceptives are still unknown for many wildlife species. For a better understanding on how to provide adequate means of population control, more studies are needed.

\section{REFERENCES}

Bertschinger, H.J., M.A.V.B. Guimarães, T.E. Trigg \& A. Human (2008). The use of deslorelin implants for the long-term contraception of lionesses and tigers. Wildlife Research 35(6): 525-530; http:// dx.doi.org/doi.org/10.1071/WR07141

D’Occhioa, M.J., Fordyceb, G., Whytea, T.R., Aspdena, W.J., Trigg, T.E. (2000). Reproductive responses of cattle to GnRH agonists. Animal Reproductive Science (60-61): 433-442; http://dx.doi.org/10.1016/ S0378-4320(00)00078-6

European Association of Zoos and Aquariums (2010). Best Practice Guidelines Callithrichidae. http://www.eaza.net/assets/Uploads/ CCC/2015-Callitrichids-EAZA. Accessed on 09/2015.

Flaiban, K.K.M.C., K.A.H. Spohr, L.S. Malanski, W.K. Svoboda, M.M. Shiozawa \& C.L.S. Hilst (2009). Hematologic values of free-ranging Black-and-Gold Howlers Monkeys (Alouatta caraya) from the region of Upper Paraná River, southern Brazil. Arquivo Brasileiro de Medicina Veterinária e Zootecnia 61(3); http://dx.doi.org/10.1590/ S0102-09352009000300016

Gobello, C. (2007). New GnRH analogs in canine reproduction. Animal Reproduction Science 100(1\&2): 1-13; http://dx.doi.org/10.1016/j. 
anireprosci.2006.08.024

Herbet, C.A., T.E. Trigg \& D.W. Cooper (2004) Effect of deslorelin implants on follicular development, parturition and post-partum oestrus in the Tammar Wallaby (Macropus eugenii). Reproduction 127: 265-273; http://dx.doi.org/10.1530/rep.1.00094

Herbet, C.A., Trigg, T.E, Cooper, D.W. (2007) Chronic Treatment of Male Tammar Wallabies with Deslorelin Implants During Pouch Life: Effects on Development, Puberty, and Reproduction in Adulthood Biology of Reproduction 76(6): 1054-1061; http://dx.doi. org/10.1095/biolreprod.107.059915

Kauffold J., H. Rohrmann \& J. Boehm (2010). Effects of long-term treatment with the $\mathrm{GnRH}$ agonist deslorelin (Suprelorin ${ }^{\circledR}$ ) on sexual function in boars. Theriogenology 74: 733-740; http://dx.doi. org/10.1016/j.theriogenology.2010.03.026

Kutzler, M. \& A. Wood (2006). Non-surgical methods of contraception and sterilization. Theriogenology 66(3): 514-516; http://dx.doi. org/10.1016/j.theriogenology.2006.04.014

McClintock, M.K. (1983) Synchronizing Ovarian and Birth Cycles by Female Pheromones', pp. 159-78. In: Dietland Müller-Schwarze, D \& R.M. Silverstein (eds.). Chemical Signals in Vertebrates 3 Edition. Springer US; http://dx.doi.org/10.1007/978-1-4757-9652-0_10

Mittermeier, R.A., A.B. Rylands \& A.F. Coimbra-Filho (1988) Systematics: species and subspecies - an update; pp. 13-75. In: Mittermeier, R.A., A.B. Rylands, A.F. Coimbra-Filho \& G.A.B. da Fonseca (eds.). Ecology and Behavior of Neotropical Primates Vol. 2. World Wildlife Foundation, Washington D.C.; http://dx.doi. org/10.1007/978-1-4419-0293-1_2

Modesto, Thiago C., Bergallo, Helena G. (2008). Ambientes diferentes, diferentes gastos do tempo entre atividades: o caso de dois grupos mistos do exótico Callithrix spp. na Ilha Grande, RJ, Brasil. Neotropical Biology and Conservation 3(3): 112-118; http://dx.doi. org/10.4013/nbc.20083.02

Munro, C.J., G.H. Stabenfeldt, J.R Cragun, L.A. Addiego, J.W. Overstreet \& B.L. Lasley (1991). Relationship of serum estradio and progesterone concentrations to the excretion profiles of their major urinary etabolites as measured by enzyme immunoassay and radioimmunoassay. Clinical Chemistry 37(6): 838.

Munson, L., C.S. Bauman, C.S. Asa, W. Jochle \& T.E. Trigg (2001). Efficacy of the $\mathrm{GnRH}$ analogue deslorelin for suppression of oestrous cycles in cats. Journal of Reproductive Fertility Supplement 57: 269273.

Ortmann, O., J.M. Weiss \& K. Diedrich (2002). Gonadotrophinreleasing hormone $(\mathrm{GnRH})$ and $\mathrm{GnRH}$ agonists: mechanisms of action. Reproductive BioMedicine 5(Supplement 1): 1-7; http:// dx.doi.org/10.1016/S1472-6483(11)60210-1

Padula, A.M. (2005). GnRH analogues-agonists and antagonists. Animal Reproduction Science 88(1-2): 115-126;http://dx.doi. org/10.1016/j.anireprosci.2005.05.005

Munro, C. \& G. Stabenfeldt (1984). Development of a micro-titer plate enzyme immunoassay for the determination of progesterone. Journal of Endocrinology 101: 41-49; http://dx.doi.org/10.1677/ joe.0.1010041

Pizzutto, C., M.G.F.G. Sgai, C.P. Francischini, P. Viau, C.A. Oliveira \& M.A.B.V. Guimarães (2015). Physiological validation of enzyme immunoassay of fecal glucocorticoid metabolite levels and diurnal variation measured in captive Black-tufted Marmoset Callithrix penicillata (Mammalia: Primates: Callitrichidae). Journal of Threatened Taxa 7(6): 7234-7242; http://dx.doi.org/10.11609/ JoTT.04099.7234-42

Richardson, D.M., P. Pyšek, M. Rejmánek, M.G. Barbour, F.D. Panetta \& C.J. West (2000). Naturalization and invasion of alien plants: concepts and definitions. Diversity and Distributions 6: 93-107; http://dx.doi.org/10.1046/j.1472-4642.2000.00083.x

Saltzman, W., B.K. Hogan, B.M. Horman \& D.H. Abbott (2006). Social suppression of cortisol in female Marmosets: Role of luteinizing hormone/chorionic gonadotropin. General and Comparative Endocrinology 149(2006): 90-99; http://dx.doi.org/10.1016/j. ygcen.2006.05.007

St. Luis Zoo Contraceptive Center (2015). New World MonkeysPrimates; General Recommendations; GnRH Agonists. Accessed on $09 / 2015$

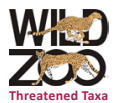

Portuguese Abstract: Deslorelina é um GnRH- análogo sintético, utilizado como um contraceptivo em animais, atuando como um supressor gonadal. O produto Suprelorin (Virbac, AU) contém deslorelina, um implante subcutâneo, bio-compaivel, com liberação lenta. A liberação contínua e lenta de deslorelina provoca um efeito de "down-regulation", ou seja, baixando a expressão dos receptores para GnRH e, posteriormente, inibição da síntese e liberação das gonadotrofinas FSH e LH, necessário para atividades gonadal. A intenção deste estudo foi investigar a eficácia de um implante subcutânea de acetato de deslorelina $(2,35 \mathrm{mg})$ na supressão da atividade cíclica do ovário, a inibição da ovulação em sagüis de tufo-branco (Callithrix jacchus) e, posteriormente, investigar a reversibilidade do tratamento. Para este desígnio, dois grupos experimentais foram formados, Grupo de deslorelina (D), com três casais e um grupo controle (C), com dois casais. Com objetivo de monitorar o efeito dos implantes, amostras de fezes das todas as fêmeas foram coletadas três vezes por semana, durante três fases diferentes (fase Um, três meses; fase Dois, três meses, e de fase Três, quatro meses). A observação dos efeitos dos implantes, hormônios indicando atividade cíclica ovariana foram monitorados não invasivamente por análise de imunoensaio de enzima (fecal anticorpo anti-progesterona monoclonal CL 425). Amostras fecais foram coletadas três vezes por semana de todas as fêmeas, durante as três fases experimentais (fase I: mês 1,2,3 e 4; fase II: mês: 5,6 e 7 e fase III: mês 8,9 e 10). Ao contrário das expectativas, os resultados deste experimento indicaram que não havia nenhuma supressão da atividade cíclica ovariana, nem inibição ovulatória, após a aplicação dos implantes. $O$ resultado do nosso experimento pode possivelmente ser explicado pelo fato de que a dosagem de 2,35 $\mathrm{mg}$ de deslorelina não é eficaz em $C$. jacchus. No entanto, mudanças significativas ( $p<$ $0,05)$ dos metabolitos P4 da Fase I a Fase II, devido ao tratamento, foram confirmados. O método de monitorização utilizada para os metabolitos fecais de progesterona (P4) foi validado biologicamente e demonstrou ser eficiente para a detecção da atividade cíclica ovariana na espécie de primatas neotropicais, $C$. jacchus. 